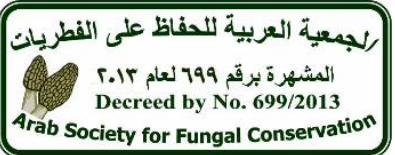

Contents lists available at Egyptian Knowledge Bank

Microbial Biosystems

Journal homepage: http://mb.journals.ekb.eg/

\title{
Poroid fungi (Agaricomycetes, Basidiomycota) from Floresta Nacional de Silvânia - a conservation unit of Brazilian Savanna
}

\section{Leonardo-Silva L, Silva LB and Xavier-Santos $S^{*}$}

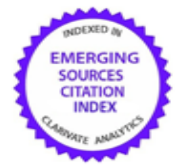

Universidade Estadual de Goiás. Campus Anápolis de Ciências Exatas e Tecnológicas, Laboratório de Micologia Básica, Aplicada e Divulgação Científica - FungiLab. Rod. Br 153, Km 99, Anápolis, Goiás, Brazil.

\begin{tabular}{l}
\hline ARTICLE INFO \\
\hline Article history \\
Received 11 June 2020 \\
Received revised 29 June 2020 \\
Accepted 2 July 2020 \\
Available online 2 July 2020 \\
C Leonardo-Silva et al. 2020 \\
Corresponding Editor: \\
Singh PP \\
Yadav AN \\
Balbool BA \\
Keywords \\
Biodiversity \\
Cerrado \\
Hymenochaetales \\
Mycobiota \\
Polyporales
\end{tabular}

\begin{abstract}
We present a taxonomic inventory, including ecological aspects, of poroid fungi from the Floresta Nacional de Silvânia, a conservation unit representative of the Brazilian Savanna (Cerrado) biome. Basidioma collection was sampled randomly (active search), between 2005 to 2012, considering the conservation unit area, and occurred along or outside preexisting trails, mainly within forest formations. Totally we found 27 species, distributed into 22 genera, 9 families and 3 order. The $\alpha$ diversity $\left(\mathrm{H}^{\prime}\right)$ was 2.86; the maximum diversity estimated ( $\mathrm{H}$ max) was 3.29 and the Pielou equability $\left(\mathrm{J}^{\prime}\right)$ was 0.87 . These data, added to species accumulation curve, indicate that the number of species of poroid fungi found has not yet exhausted the real diversity of the area and it may increase with the increase in collections (sampling effort). About $37 \%$ of the species were found in both living and decaying wood; $33 \%$ exclusively in dead and $22 \%$ exclusively in alive wood. Among these, $44 \%$ were classified as rare in the area, 33\% occasional, $15 \%$ common and $7 \%$ abundant. The most frequent species were those that occurred in both living and decaying wood, while the rare ones occurred exclusively in one type of wood (living or dead). The present work is one of the pioneers in the study of poroid fungi in Central Brazil, increasing the knowledge of this biodiversity in the Brazilian Savanna, which can be used as support to update the management plan of the conservation unit.
\end{abstract}

Published by Arab Society for Fungal Conservation

\section{Introduction}

The Floresta Nacional (FLONA) de Silvânia was created by Law 612 on January 13, 1949, as Horto Florestal de Silvânia, Goiás, Brazil. In 2001, the Horto was elevated to the National Forest category, by IBAMA Ordinance 247 of July 18, 2001. Today, the Conservation Unit (CU) is managed by the Chico Mendes Institute for Biodiversity

\footnotetext{
* Corresponding author

E-mail address: solange.xavier@ueg.br (Solange Xavier dos Santos)
}

Conservation (ICMBio), a federal agency created by Law 11516, on August 28, 2007 (Marques et al. 2009; ICMBio 2015). Among the federal conservation units of the Brazilian Savanna (Cerrado biome) managed by ICMBio, the Silvânia's FLONA is considered the oldest (ICMBio 2020).

Silvânia's FLONA aims to promote the proper management of natural resources, guarantee the protection 
of water and scenic beauty, in addition to configuring an $30 \%$ of the known species of biodiversity in Brazil, important source for the development of basic and applied however, due to human activities, more than $50 \%$ of the scientific research, as well as new technologies, environmental education, recreation, leisure and tourism activities (Marques et al. 2009; Morais et al. 2012; ICMBio 2015). It is a CU whose protected area has representative typical vegetation types of Cerrado, such as campo sujo, cerrado sensu stricto, vereda, cerradão, mata seca and mata de galeria (ICMBio 2015).

The Brazilian Savanna, known as the Cerrado, is formed by a mosaic of ecologically related communities and has an area that covers the states of Central Brazil and part of the Northern, Northeastern, Southern and Southeastern regions (Fig. 1), constituting one of the largest Brazilian biomes by area, second only to the Amazon Forest (Ribeiro and Walter 2008). Its climate is characterized by two well-defined seasons, the rainy season, which lasts from October to March and the dry season, from April to September. This biome is composed of several types of landscapes, resulting in a vegetation mosaic, with phytophysiognomies that vary between savanna and forest formations (Klink and Machado 2005;

biome has already been deforested and fragmented, and only 3\% are in conservation units. (Françoso et al. 2015; WWF 2020).

Included in this Cerrado biodiversity are poroid fungi, which play an important role in nutrient cycling within ecosystems, in addition to being the principle decomposers of wood. These fungi represent a large artificial group within the Agaricomycetes class. They are so named because the hymenophore is made up of fused vertical tubes, called pores (Kirk et al. 2008). There are about 175 species of poroid fungi listed for the Brazilian Savanna (Gibertoni and Drechsler-Santos 2010; Abrahão et al. 2012; Costa-Rezende et al. 2015; Maia et al. 2015; CostaRezende et al. 2016; Bononi et al. 2017; Leonardo-Silva et al. 2020); of these, only nine have been recorced occuring in the state of Goiás. This present study presents the first taxonomic inventory of poroid fungi from Silvania's FLONA, and includes ecological aspects of the group. Ribeiro and Walter 2008). The Cerrado has approximately
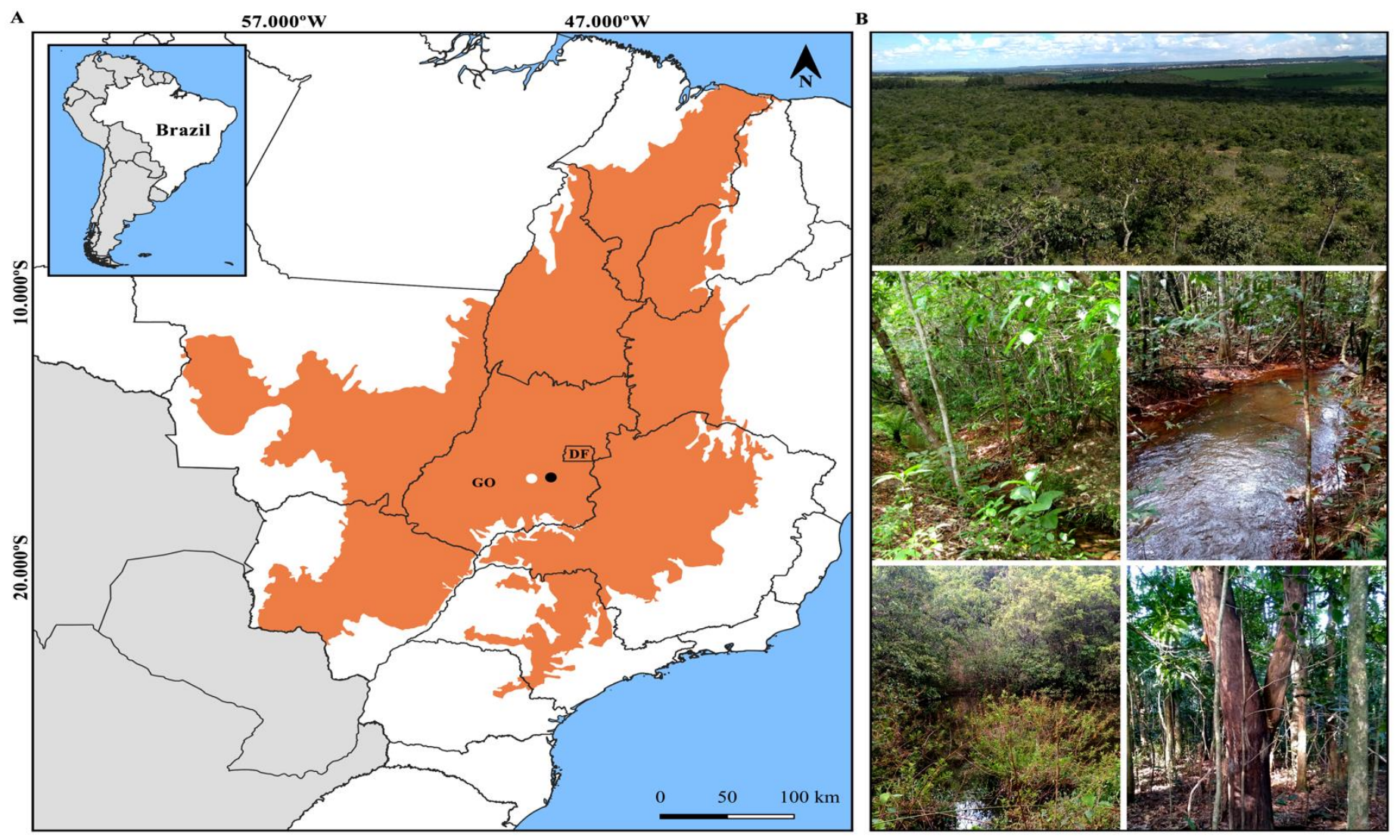

Fig 1. Studied area. A. Location: In orange the distribution area of Brazilian Savanna; black dot indicates the location of the Floresta Nacional (FLONA) de Silvânia in the state of Goiás; white dot represents Goiânia (capital of the state of Goiás) and DF represents the Distrito Federal, where the country's capital Brasília is located. B. Some phytophysiognomies of the Brazilian Savanna in Silvânia's FLONA. 


\section{Materials \& Methods}

The Silvânia's FLONA is located in the municipality of Silvânia, in the eastern portion of the state of Goiás, $88 \mathrm{~km}$ from Goiânia (the state capital) and $177 \mathrm{~km}$ from Brasília (the capital of the country), between $16^{\circ} 38^{\prime} 30.0^{\prime \prime} \mathrm{S}$ and $48^{\circ} 39^{\prime} 02.5^{\prime \prime} \mathrm{W}$, and has an area of 486.37 ha (Fig. 1). The average altitude is $900 \mathrm{~m}$, and its average temperature is 26 ${ }^{\circ} \mathrm{C}$. The CU administrative headquarters has accommodation, a research support house and a library with more than 500 titles on fauna, flora and ecology for research and reading. Along its length, there are internal roads, for the observation of local fauna, flora and mycobiota and trails, among which is one with about $1 \mathrm{~km}$, composed of gallery forest in transition with the cerradão, and one with $2.5 \mathrm{~km}$ extension, through the densest forest (ICMBio 2015). The sampling took place between 2005 to 2012. Basidioma collection was sampled randomly (active search), considering the $\mathrm{CU}$ area, and occurred along or outside pre-existing trails, mainly within forest formations. Taxonomic identification was performed based on the macro and micromorphological characteristics of the collected material, using specialized literature as a reference (Teixeira 1995; Ryvarden 2004). The classification and nomenclature of the cited taxa is in accordance with the Index Fungorum (2020). Voucher of the studied specimens were deposited in the Herbarium of the Universidade Estadual de Goiás (HUEG).

For ecological analyses, the absolute frequency (AF) was determined for each species, that is the absolute number of occurrences of the species and the relative frequency (RF) that presents the ratio between the AF of a species and the sum of the AFs of all species inventoried, given as a percentage (Mungai et al. 2011). The frequency classes of each species were designated using the same criteria established by Lindblad (2000), Hattori (2005) and Soares et al. (2014): $0.5<\mathrm{RF} \leq 1.5 \%$ are considered as rare $(\mathrm{R}) ; 1.5<\mathrm{RF} \leq 5 \%$, are occasional $(\mathrm{O}) ; 5<\mathrm{RF} \leq 10 \%$ are given as common $(\mathrm{C})$; RF> $10 \%$ are considered abundant (A).

To verify $\alpha$ diversity, the Shannon-Wiener diversity index $\left(\mathrm{H}^{\prime}\right)$ was used, which takes into account the uniformity of species abundances by measuring the number of equally common species (Shannon 1948). The maximum diversity index ( $\mathrm{H} \max )$ was also calculated. Through the ratio between $\mathrm{H}^{\prime}$ and $\mathrm{H}$ max, the Equity Index $\left(\mathrm{J}^{\prime}\right)$ was obtained, which represents a measure of uniformity constrained between 0 and 1.0 (Rebêlo and Garófalo 1997; Magurran 1988).

\section{Results and Discussion}

We documented 27 species of poroid fungi in the area, which are distributed into 22 genera, 9 families and 3 orders (Figs. 2 and 3). Polyporaceae was most represented family, with 49 occurrences, 8 genera, 11 species, followed by Hymenochaeteaceae, represented by 7 occurences, 4 genera and 5 species (Table 1). The representation of these families is in accordance with expectations, as they account for the largest and most diverse group of poroid fungi, with a wide variety of shapes and structures (Kirk et al. 2008). Similar results were observed in inventories carried out in areas of the Amazon rainforest in Brazil (Soares et al. 2014; Xavier et al. 2018).

The relative frequency (RF) of each species showing that $44.4 \%$ are rare in the area, $33.3 \%$ occasional, $15 \%$ common and $7.4 \%$ abundant (Table 1). Studies carried out in the Amazon biome show that $83.3 \%$ of the species of fungi found in the FLONA in Amapá and $61.5 \%$ of the species of the FLONA in Caxiuanã are rare (Soares et al. 2014 and Medeiros et al. 2015, respectively). Gibertoni et al. (2007) and Gibertoni (2008) also report a high rate of rare species in tropical regions, showing the importance of maintaining CUs, which maintain the natural resources of these habitats and a wide variety of species.

All specimens were found on wood (dead or alive); $37 \%$ of the species were found on both live and dead wood; $33.3 \%$ exclusively in dead wood and $22.2 \%$ exclusively in live wood (resulting in $55.5 \%$ of species with specificity for live or dead wood). For $7.4 \%$ of them it was not possible to identify the state of the substrate (Table $1)$.

The great availability of woody resources in tropical forests is one of the main factors that favor the presence of poroid fungi in these environments, since these fungi are predominantly ligninocellulolitic. Although the relationship between the distribution of these fungi and the substrate is not satisfactorily clarified, varying according to the region (Ferrer and Gilbert 2003; Medeiros et al. 2015). Yamashita and Hijii (2006) point out that the diversity of fungi in an area can be affected by the specificity of substrates, including stages of decomposition, age and availability of these substrates. We found that the most frequent species of poroid fungi in the Silvânia's FLONA were those that occurred in both living and decaying wood, while the rare ones were those that occurred exclusively in one type of wood (live or dead) (Table 1). These data are in agreement with the claims of Gilbert and Sousa (2002), that the specificity by the substrate is a factor that increases the number of rare species. 
Table 1 Poroid fungi sampled in the Floresta Nacional (FLONA) de Silvânia according to taxonomy, substrate, frequency and voucher at HUEG herbaria

\begin{tabular}{|c|c|c|c|c|c|}
\hline Order/Family/Species & Substrate & $\mathrm{AF}$ & FR $(\%)$ & $\mathrm{CF}$ & HUEG voucher \\
\hline \multicolumn{6}{|l|}{ Agaricales } \\
\hline \multicolumn{6}{|l|}{ Schizophyllaceae Quél. } \\
\hline Schizophyllum commune Fr. & DLW & 6 & 7.06 & $\mathrm{C}$ & $9957-9962$ \\
\hline \multicolumn{6}{|l|}{ Hymenochaetales } \\
\hline \multicolumn{6}{|l|}{ Hymenochaetaceae Donk } \\
\hline Fomitiporia apiahyna (Speg.) Robledo, Decock \& Rajchenb. & LW & 1 & 1.17 & $\mathrm{R}$ & 9968 \\
\hline Fuscoporia callimorpha (Lév.) Groposo, Log. -Leite \& Góes-Neto & DW & 2 & 2.35 & $\mathrm{O}$ & 9963,9965 \\
\hline Fuscoporia wahlbergii (Fr.) T. Wagner \& M. Fisch. & LW & 1 & 1.17 & $\mathrm{R}$ & 9966 \\
\hline Hymenochaete rheicolor (Mont.) Lév. & $\mathrm{W}$ & 1 & 1.17 & $\mathrm{R}$ & 9967 \\
\hline Phellinus gilvus (Schwein.) Pat. & LW & 2 & 2.35 & $\mathrm{O}$ & 9964,9969 \\
\hline \multicolumn{6}{|l|}{ Incertae Sedis } \\
\hline Trichaptum perrottetii (Lév.) Ryvarden & DLW & 5 & 5.88 & $\mathrm{C}$ & $10035-10039$ \\
\hline Trichaptum sector (Ehrenb.) Kreisel & DLW & 2 & 2.35 & $\mathrm{O}$ & 10040,10041 \\
\hline \multicolumn{6}{|l|}{ Polyporales } \\
\hline \multicolumn{6}{|l|}{ Cerrenaceae Miettinen, Justo \& Hibbett } \\
\hline Cerrena hydnoides (Sw.) Zmitr. & DW & 1 & 1.17 & $\mathrm{R}$ & 10001 \\
\hline \multicolumn{6}{|l|}{ Fomitopsidaceae Jülich } \\
\hline Daedalea ryvardeniana Drechsler-Santos \& Robledo & DW & 2 & 2.35 & $\mathrm{O}$ & 9970,9971 \\
\hline \multicolumn{6}{|l|}{ Ganodermataceae Donk } \\
\hline Amauroderma calcigenum (Berk.) Torrend & DW & 1 & 1.17 & $\mathrm{R}$ & 9972 \\
\hline Ganoderma testaceum (Cooke) Pat. & LW & 3 & 3.53 & $\mathrm{O}$ & $9973-9975$ \\
\hline \multicolumn{6}{|l|}{ Panaceae Miettinen Justo \& Hibbett } \\
\hline Cymatoderma caperatum (Berk. \& Mont.) D.A. Reid & DLW & 5 & 5.88 & $\mathrm{C}$ & $9976-9980$ \\
\hline Panus strigellus (Berk.) Overh. & DW & 1 & 1.17 & $\mathrm{R}$ & 10020 \\
\hline \multicolumn{6}{|l|}{ Irpicaceae Spirin \& Zmitr. } \\
\hline Gloeoporus thelephoroides (Hook.) G. Cunn. & $\mathrm{W}$ & 1 & 1.17 & $\mathrm{R}$ & 9981 \\
\hline \multicolumn{6}{|l|}{ Steccherinaceae Parmasto } \\
\hline Antrodiella versicutis (Berk. \& M.A. Curtis) Gilb. \& Ryvarden & DW & 2 & 2.35 & $\mathrm{O}$ & 9982,9983 \\
\hline \multicolumn{6}{|l|}{ Polyporaceae Fr. ex Corda } \\
\hline Favolus tenuiculus P. Beauv. & DLW & 4 & 4.70 & $\mathrm{O}$ & $9984-9987$ \\
\hline Fomes fasciatus (Sw.) Cooke & LW & 1 & 1.17 & $\mathrm{R}$ & 9988 \\
\hline Funalia caperata (Berk.) Zmitr. \& Malysheva & DLW & 4 & 4.70 & $\mathrm{O}$ & 9989-9992 \\
\hline Funalia floccosa (Jungh.) Zmitr. \& Malysheva & DLW & 8 & 9.41 & $\mathrm{C}$ & $9993-10000$ \\
\hline Lentinus berteroi (Fr.) Fr. & DLW & 17 & 20 & A & $10002-10018$ \\
\hline Microporellus dealbatus (Berk. \& M.A. Curtis) Murrill & DW & 1 & 1.17 & $\mathrm{R}$ & 10019 \\
\hline Polyporus dictyopus Mont. & DW & 1 & 1.17 & $\mathrm{R}$ & 10021 \\
\hline Polyporus guianensis Mont. & LW & 1 & 1.17 & $\mathrm{R}$ & 10022 \\
\hline Pycnoporus sanguineus (L.) Murrill & DLW & 9 & 10.6 & A & $10023-10031$ \\
\hline Trametes pavonia (Hook.) Ryvarden & DLW & 2 & 2.35 & $\mathrm{O}$ & $10032-10033$ \\
\hline Trametes variegata (Berk.) Zmitr., Wasser \& Ezhov & DW & 1 & 1.17 & $\mathrm{R}$ & 10034 \\
\hline
\end{tabular}

Absolute frequency (AF); Relative frequency (RF); Frequency class (FC): abundant (A), common (C), occasional (O), rare (R); Dead wood (DW); Living wood (LW); Dead and living wood (DLW) and Wood (W). 

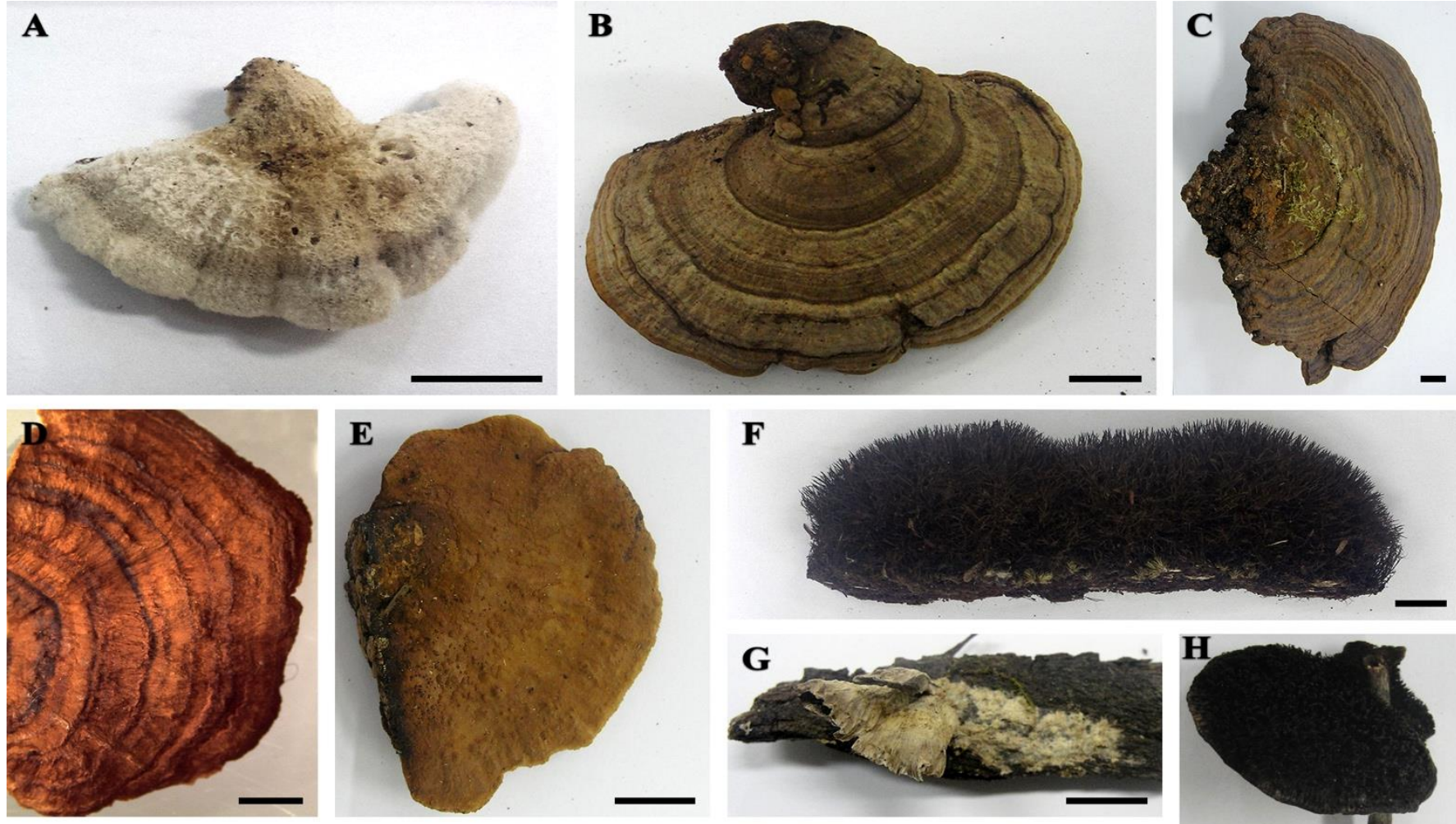

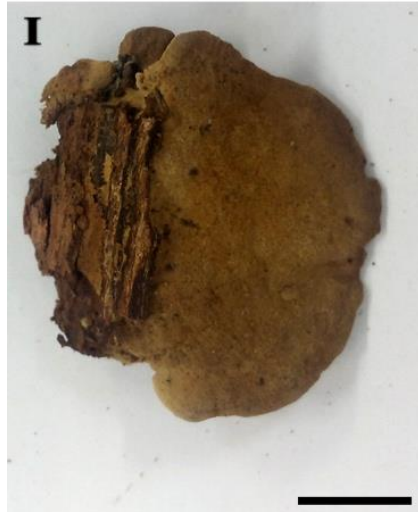

$\mathbf{J}$
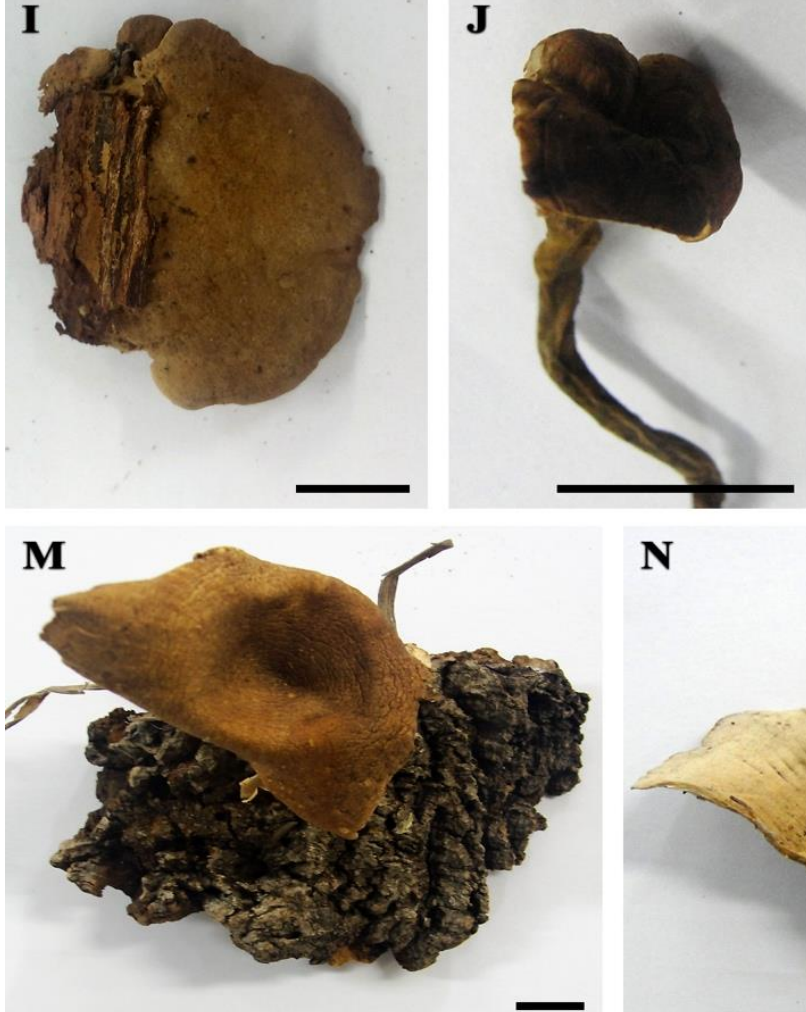

$\mathbf{N}$

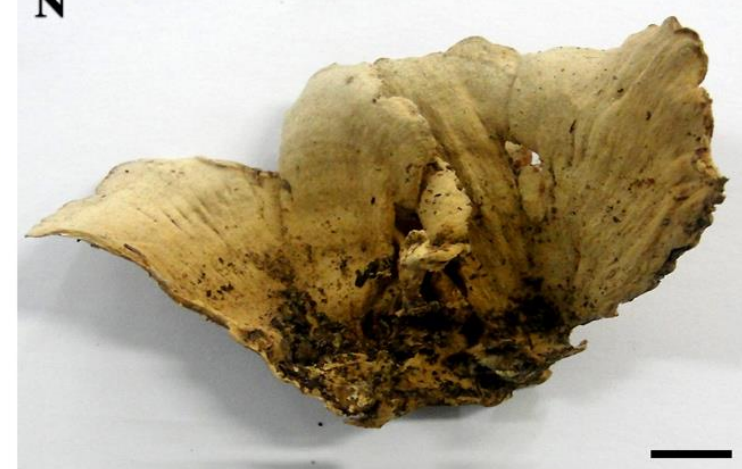

$\mathbf{L}$
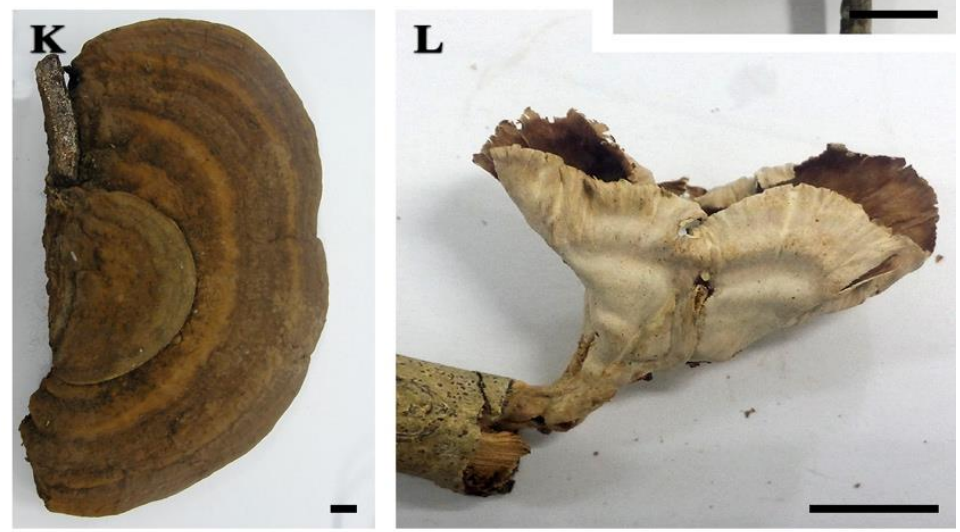

$\mathbf{O}$

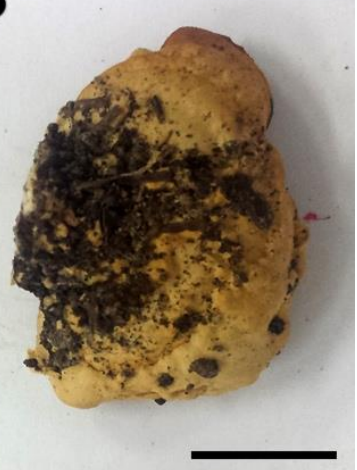

Fig 2. Recorded taxa. Basidiomata of Schizophyllum commune (A), Fomitiporia apiahyna (B), Fuscoporia wahlbergii (C), Hymenochaete rheicolor (D), Phellinus gilvus (E), Trichaptum perrottetii (F), Trichaptum sector (G), Cerrena hydnoides (H), Daedalea ryvardeniana (I), Amauroderma calcigenum (J), Ganoderma testaceum (K), Cymatoderma caperatum (L), Panus strigellus (M), Gloeoporus thelephoroides $(\mathrm{N})$ and Antrodiella versicutis $(\mathrm{O})$. Bars $\mathrm{A}-\mathrm{C}, \mathrm{E}-\mathrm{O}=1 \mathrm{~cm} ; \mathrm{D}=2 \mathrm{~mm}$. 

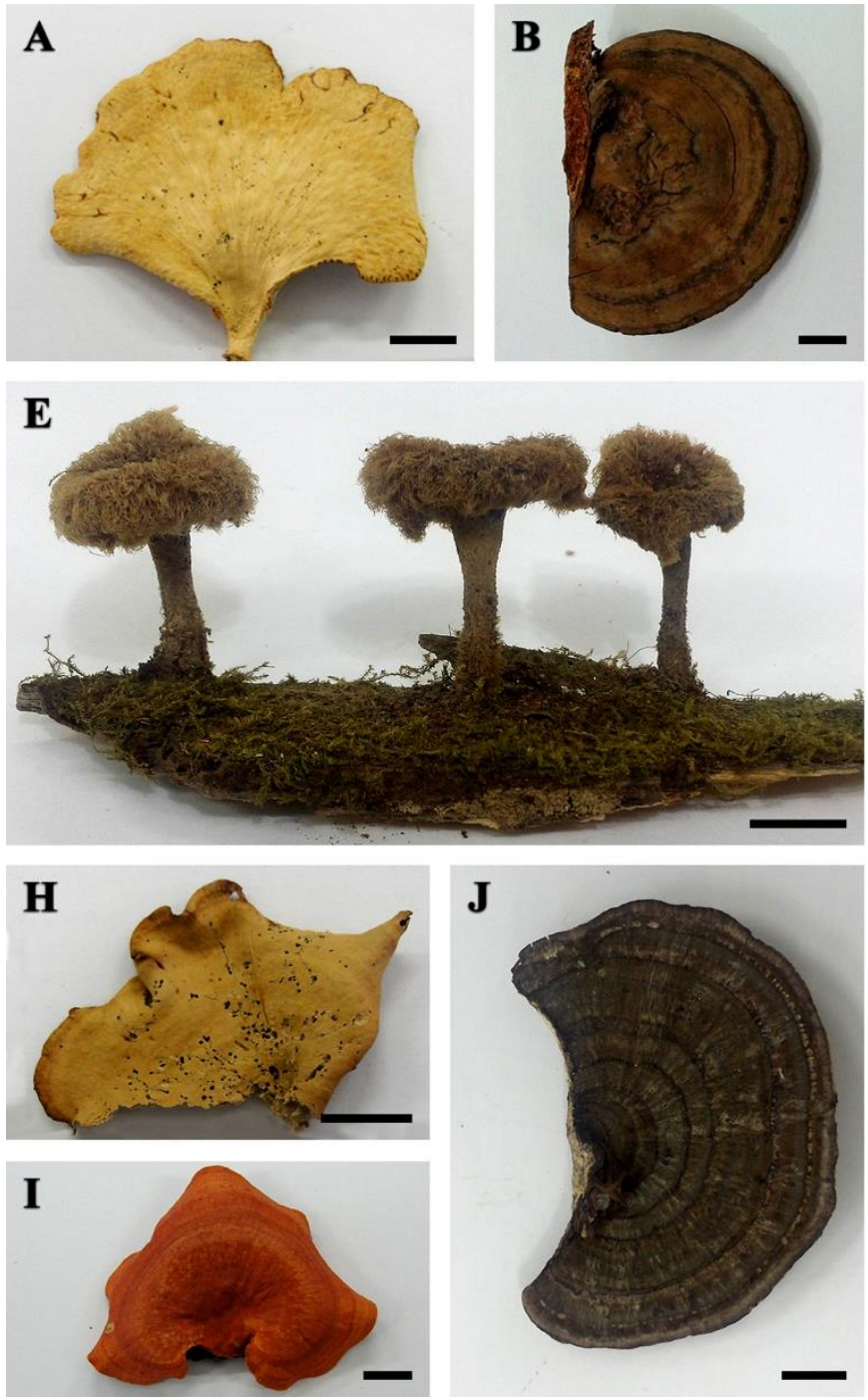
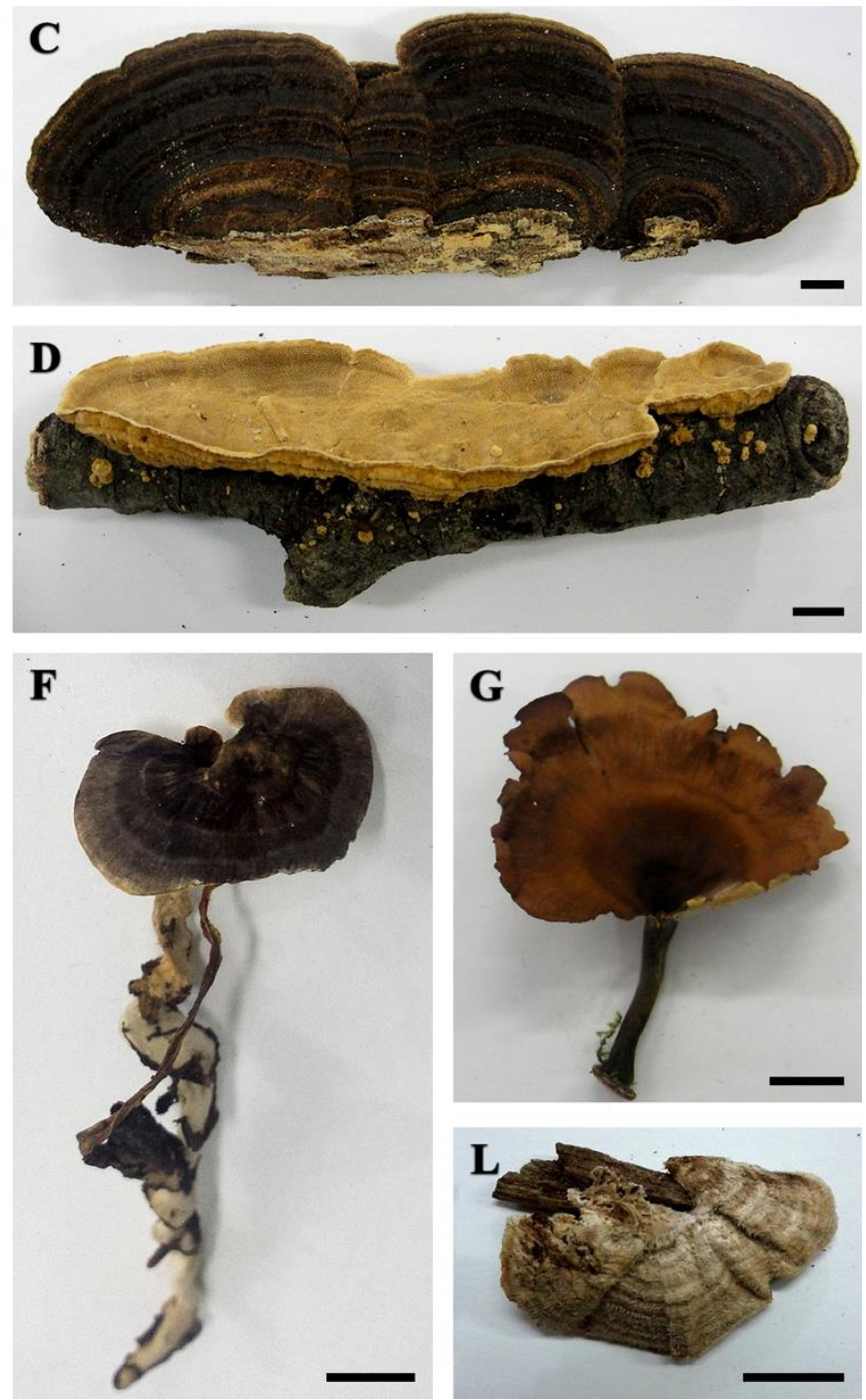

Fig 3. Recorded taxa. Basidiomata of Favolus tenuiculus (A), Fomes fasciatus (B), Funalia caperata (C), Funalia floccosa (D), Lentinus berteroi (E), Microporellus dealbatus (F), Polyporus dictyopus (G), Polyporus guianensis $(\mathrm{H})$, Pycnoporus sanguineus (I), Trametes pavonia (J) and Trametes variegata (L). Bars $=1 \mathrm{~cm}$.

The species accumulation curve generated according to species collected per year, did not reach asymptote, thus indicating that the richness of poroid fungi in the area may increase with the increase in collections (sampling effort). This result is similar to those found by Soares et al. (2014), Medeiros et al. (2015) and Xavier et al. (2019), who despite having found great richness in the studied areas, also obtained non-asymptotic accumulation curves.

The $\alpha$ diversity, estimated through the ShannonWiener index $\left(\mathrm{H}^{\prime}\right)$, was 2.86 . The maximum diversity index ( $\mathrm{H}$ max) was 3.29. The $\mathrm{H}^{\prime}$ value lower than the $\mathrm{H}$ max reaffirms the data of the species accumulation curve, indicating that the number of species found has not yet exhausted the real diversity of the area. Pielou's equability $\left(\mathrm{J}^{\prime}\right)$ was 0.87 , which indicates that the number of records is uniform among the sampled species.

Inventories of fungi help to document a local diversity and to understand ecological and biogeographic relationship of these species in ecosystems, highlighting their richness, abundance, frequency, substrate and others. These studies help in the elaboration of measures to conserve the biodiversity of the local mycobiota, in status of habitat (environmental quality) and know potential species of economic interest, besides being an important tool in the promotion of mycophilia (Soares et al. 2014; Mouchacca 2016; Karun et al. 2018; Xavier et al. 2018; Kotowski 2019).

The present work is one of the pioneers in the study of poroid fungi within areas of the Cerrado of Central Brazil and the diversity inventoried evidences the need to 
intensify researches in both taxonomy and ecology, which allows for representation of the richness of fungal species and their exosystemic role.

Moreover, further research will make it possible to expand the knowledge of the economic potential of the local mycobiota. In addition, the diversity of poroid fungi from the Silvânia's FLONA showed great richness and a high number of species considered rare, which adds value to biotic factors and can be used in appliance to update the management plan of the conservation unit.

\section{Conflict of Interest}

The authors do not have any conflicts of interest.

\section{Acknowledgements}

We are grateful to the Coordenação de Aperfeiçoamento de Pessoal de Ensino Superior (CAPES), for granting a doctoral scholarship to the first author; to the administration of Floresta Nacional (FLONA) de Silvânia for the support and authorization for collections in the area, to Hunter Lee Daniel, for reviewing the English language in the manuscript and to Dr. Tatiana Baptista Gibertoni for the identification of some species.

\section{References}

Abrahão MC, Gugliotta AM, Bononi VLR 2012 Xylophilous Agaricomycetes (Basidiomycota) of Brazilian Cerrado. CheckList 8:1102-1116.

Bononi VLR, Oliveira AKM, Gugliotta AM, Quevedo JR. 2017. Agaricomycetes (Basidiomycota, Fungi) diversity in a protected area in the Maracaju Mountains, in the Brazilian central region. Hoehnea 44:361-377.

Costa-Rezende DH, Ferreira-Lopes V, Salvador-Montoya CA, Alves-Silva G, Mello A, Drechsler-Santos ER 2015 Novos registros de Perenniporia s. 1. e Pyrofomes para o Cerrado Brasileiro. Iheringia 70:157-166.

Costa-Rezende DH, Gugliotta AM, Góes-Neto A, Reck MA, Robledo GL, Drechsler-Santos ER 2016 Amauroderma calcitum sp. nov. and notes on taxonomy and distribution of Amauroderma species (Ganodermataceae). Phytotaxa 244:101-124.

Ferrer A, Gilbert GS 2003 Effect of tree host species on fungal community composition in a tropical rain forest in Panama. Div Distrib 9:455-468.

Françoso RD, Brandão R, Nogueira CC, Salmona YB, Machado RB, Colli GR 2015 Habitat loss and the effectiveness of protected areas in the Cerrado biodiversity hotspot. Natur Conser 13:35-40.

Gibertoni TB, Drechsler-Santos ER 2010. Lignocellulolytic Agaricomycetes from the Brazilian Savannah biome. Mycotaxon 111:87-90.

Gibertoni TB, Santos PJP, Cavalcanti MAQ 2007 Ecological aspects of Aphyllophorales in the Atlantic Rain Forest in Northeast Brazil. Fung Diver 25:49-67.

Gibertoni TB 2008 Polyporoid fungi (Agaricomycetes, Basidiomycota) in the Estação Científica Ferreira Penna (State of Pará, Brazilian Amazonia): diversity and ecological aspects. Sci Acta 2:70-74.

Gilbert GS, Sousa WP 2002 Host specialization among 106 wood-decay polypore fungi in a Caribbean mangrove forest. Biotropica 34:396-404.

Hattori T 2005 Diversity of wood-inhabiting polypores in temperate forest with different vegetation types in Japan. Fung Diver 18:73-88.

ICMBio - O Instituto Chico Mendes de Conservação da Biodiversidade. 2015. Plano de Manejo da Floresta Nacional de Silvânia. Volume I - Diagnóstico. 297 p.

ICMBio - O Instituto Chico Mendes de Conservação da Biodiversidade. 2020. Unidades de Conservação Cerrado. Accessed May 31, 2020.

https://www.icmbio.gov.br/portal/unidadesdeconservacao /biomas-brasileiros/cerrado/unidades-de-conservacaocerrado.

Index Fungorum 2020. Accessed May 31, 2020. http://www.indexfungorum.org/.

Karun NC, Bhagya BS, Sridhar KR 2018 Biodiversity of macrofungi in Yenepoya campus, Southwest India. Microb Biosyst 3:1-11.

Kirk PM, Cannon PF, Minter DW, Stalpers JA 2008 Ainsworth \& Bisby's Dictionary of the Fungi. $10^{\text {rd }}$ edition, CAB International, United Kingdom. 784 p.

Klink CA, Machado RB 2005 A conservação do Cerrado Brasileiro. Megadiv 1:147-155.

Kotowski MA. 2019. History of mushroom consumption and its impact on traditional view on mycobiota-an example from Poland. Microb Biosyst 4:1-13.

Leonardo-Silva L, Silva LB, Sá ASF, Naves LRR, Cunha EL, Xavier-Santos S 2020 Additions to the knowledge of Ganodermataceae in brazilian Cerrado. Hoehnea 47: 1-7.

Lindblad I 2000 Host Specificity of Some WoodInhabiting Fungi in a Tropical Forest. Mycologia 92:399-405.

Magurran AE 1988 Ecological diversity and its measurement. New Jersey: Princeton University Press. 
$179 \mathrm{p}$.

Maia LC, Carvalho AA, Júnior Cavalcanti LH, Gugliotta AM, Drechsler Santos ER, Santiago ALMA 2015 Diversity of Brazilian fungi. Rodri 66:1033-1045.

Marques BF, Marques CRS, Roriz GFS 2009 A concessão de florestas públicas. Rev Facul Dir - Uni Fed Goi 33: 89-111.

Medeiros OS, Cattanio JH, Sotão HMP 2015 Riqueza e relação dos fungos poroides lignolíticos (Agaricomycetes) com o substrato em floresta da Amazônia. Bol Mus Par Emí Go - Ciê Nat 10: 423 436.

Morais AR, Bastos RP, Vieira R, Signorelli L 2012 Herpetofauna of the Floresta Nacional de Silvânia, a Cerrado remnant in Central Brazil. Neotr Biol Cons 7: 114-121.

Mouchacca J. 2016. Mycological discoveries in the Middle East region in the second part of the last century. Microb Biosyst 1:1-39.

Mungai P, Hyde KD, Njogu J, Chukeatirote E 2011 Coprophilous ascomycetes of northern Thailand. Current Res Envir App Myc 1:135-159.

Rebêlo JMM, Garófalo CA 1997 Comunidades de machos de Euglossini (Hymenoptera: Apidae) em Matas Semidecíduas do nordeste do estado de São Paulo. An Soc Ent Bras 26: 243-255.

Ribeiro JF, Walter BMT. 2008. As principais fitofisionomias do bioma Cerrado. In: Sano SM, Almeida SP, Ribeiro JF. Cerrado: Ecologia e Flora,
Brasília: Embrapa Cerrados: Emb infor tecn. 1279 p.

Ryvarden L 2004 Neotropical polypores: Part 1. Introduction, Ganodermataceae \& Hymenochaetaceae. Syn Fung 19:1-227.

Shannon CE 1948 A mathematical theory of communication. Bel Sys Tech J, 27:379-423.

Soares MAS, Sotão HMP, Medeiros OS, Gibertoni TB 2014 Riqueza de fungos Poliporoides (Agaricomycetes, Basidiomycota) em uma floresta ombrófila densa no Amapá, Amazônia Brasileira. Bol Mus Biol Mel Lei 35: 5-18.

Teixeira AR 1995 Métodos para estudo das hifas do basidiocarpo de fungos poliporáceos. Instituto de Botânica. 20 p.

WWF - World Wide Fund for Nature 2020 The "Big Five" of the Cerrado. WWF Brasil. 10 Sep 2015. Accessed May 31, 2020.

https://www.wwf.org.br/informacoes/english/?50242/The -Big-Five-of-the-Cerrado.

Xavier WKS, Sotão HMP, Soares MAS, Gibertoni TB, Rodrigues FJ, Ryvarden L 2018 Riqueza de Agaricomycetes poroides da Serra do Navio, Amazônia oriental, com novo registro de Oxyporus lacera para o Brasil. Bol Mus Par Emí Goe- Ciê Natu 13:303-315.

Yamashita S, Hijii N. 2006. Spatial distribution of the fruiting bodies of Agaricales in a Japanese red pine (Pinus densiflora) forest. J For Res 11:181-189. 